\title{
Digesting a Pandemic: Exploring Food and Nutrition Responses to the COVID-19 Outbreak
}

Ann Fox, PhD, PDt

In the summer of 2020, I wondered what the role of food and nutrition could be in managing COVID-19, and how my colleagues working in various sectors of the food and nutrition world were coping. Some aspects of food had garnered a lot of attention, particularly how to ensure a robust supply of the many products to which we had become accustomed. In Canada, we experienced food challenges we could not have anticipated a year earlier. We saw grocery store shelves cleared of staple supplies (Taylor, Pritchard, Duand, \& Mishra, 2020), grocery workers given modest temporary pay increases to keep stores open (Turnbull, 2020), and ongoing supply chain delays among giant retailers (Taylor, Pritchard, Duand, \& Mishra, 2020). Meat packing plants were threatened with closure (Yearby, 2021; Taylor, Boulos, \& Almond, 2020), border restrictions were applied to migrant farm workers (Hastie, 2020; Lupton, 2020), and warehouses such as Amazon, become hotspots for virus outbreaks (Shalvey, 2020). Truck drivers who transport goods from one end of the continent to the other, endured long hours and high-risk working conditions, often with little access to food themselves, to keep us nourished (Beswick, 2020). Retailers scrambled to make products available through online purchasing forums, and uptake of shopping options such as "click and collect" surged in popularity (Charlebois, 2020).

Relatively little however, has permeated the popular press, on the impact of nutrition itself on COVID-19. This is not because there is nothing to write about. A quick Google Scholar search of "Nutrition and COVID-19" generated 597,000 results. A plethora of articles on the impact of nutrients on the immune system (see for example Calder, 2020; Butler \& Barrientos, 2020; Derbyshire \& Delange, 2020), as well as guidelines for the nutritional management of individuals with COVID-19 (Coelho- Ravagnani, et al., 2020) can be readily found. Surprisingly however, these topics have not featured as prominently in the media as other COVID-19 topics even though analysis showing that medical treatment and research, which potentially includes nutrition, were the most frequent kinds of news stories (Liu, et al., 2020).

Curious to tease out the phenomena underway, I was grateful to the editors of Critical Dietetics for embracing the idea of a special issue devoted to COVID-19. While there was initially considerable interest in submitting papers to the edition, only three endured the editorial process, with authors citing competing demands and frank exhaustion. I think it is no coincidence that dietetics is a largely female profession (Brady, 2017). It has been well documented that women have shouldered a disproportionate amount of the COVID burden (Tam, 2020). While many have lost their jobs, others have faced the challenges of working from home while schooling children, and/or caring for older relatives (Burki, 2020). In addition, many of the high-risk (and low paying) caregiving jobs are held by women (Tam, 2020). The struggles of frontline food workers, especially those in hospitals and long-term care faculties, have yet to emerge, buried for now by the worthy but perhaps overshadowing praise bestowed on other health professionals. I believe that we need those stories to emerge.

As my dialogue with authors proceeded, it also became clear to me, that those who submitted papers, were, like me, trying to make sense of what was happening in the world around them. COVID-19 turned our lives, our communities, 
indeed our world, upside down over night. I think it is safe to say that everyone has been impacted by this Pandemic in one way or another. One experience in particular that has shaped my view of COVID-19 began on Sunday April 19, 2020 at 6:30 AM. I was awakened by an incoming text message from the premier of the province, directing universities to issue an urgent message to all students in health professional programs, seeking volunteers to help work in a longterm care facility that was experiencing an outbreak. This was the early days of the Pandemic, and one of the largest long-term care facilities in the province had been hard hit by a growing number of cases. I scrambled most of the day to get word out, only to learn by end of day, that 22 people in Nova Scotia had been killed in a mass shooting. It was a terrible day. All I could do was offer to help.

A few weeks later, I started a series of eight- hour shifts helping to feed and socialize with residents living with advanced dementia at the long-term care residence. My arrival some days coincided with that of the coroner, who was gathering the bodies of those who had died the night before. While the situation felt dire, it also provided an opportunity to witness the best of humanity. Caregivers came from organizations around the province to help. Local businesses provided an ongoing supply of food and beverages, to keep workers going. (I feel it important to note that the outbreak was not the result of neglect or poor management). Community members came out to cheer workers as they entered the building each day. We functioned as a team, helping each other to don and doff our personal protective equipment properly, and offer each other words of encouragement. I knew that this was a transformative moment for me and I wondered what other dietitians' Pandemic experiences might be.

I have come to recognize the importance of reflection during times such as these and thank the fournal for supporting this reflective edition. I am also grateful to the authors who invested the time and interpretive energy to share their stories. Jeannine Kralt and Donald Cole came together as staff member and eater-volunteer to share the experiences of Eat Local Grey Bruce (ELGB) a non-profit food cooperative in Ontario. Their story not only reminds us of the enormous challenges facing local farmers on a regular basis, but also sheds light on both the strengths and vulnerabilities of local food systems in times of crisis. It is notable that ground zero for the COVID-19 outbreak may well have been a local food market in Wuhan, China (Galanakis C. M., 2020; Jalava, 2020). We can and must do better to incentivize and support those who grow, produce and distribute local healthy food using environmentally sustainable methods. Feeding our future is in their hands.

Clare Pettinger, a dietitian in the United Kingdom, explores some of the social injustices that were laid bare during the Pandemic, and the ways that COVID-19 disproportionately affected some community members more than others. Through the songs she wrote at various stages of the Pandemic, she "aims to disrupt and dislodge" the ways of thinking about food systems, and in so doing challenges us to do the same. The media is rich with stories on the hobbies and activities people have taken up during this crisis, but Clare's work shows us through song-writing, that the arts are much more than a way of passing time. The arts are a vital resource for resilience, a mechanism for reflecting and sharing, and a tool for making sense out of what often seems senseless (Walsh, 2020). Clare's work reminds us of the importance of developing resilience in ourselves and others.

I remind readers that these stories are situated within the context of the western world. While this in no way minimizes the challenges we all continue to face, it also does not capture the ways that COVID-19 is playing out in low and middle income countries where war, climate disaster, human rights violations and poverty play out with even more profound consequences (Winskill, et al., 2020). As promoters of food justice, we must find ways for these stories to be told and heard.

I have also wondered many times in the past year, how the Pandemic is informing the generation of dietitians who are starting their careers in this environment. How will the unique learning experiences presented by COVID-19 protocols shape the values, perspectives and skill sets of today's students and interns? Kelsey Gill's reflection on her first placement in a dietetic internship offers insight and assurance that she and her peers have the capacity to learn important lessons and carry them forward. Appreciating food work that is often hidden and undervalued is a lightbulb moment with significant policy implications (e.g. decent wages, sick time, health benefits, workplace safety, training supports). Kelsey's insight provides optimism that COVID-19 will serve as a moment in history that brings about fair treatment of workers and more equitable paths to health. 
I feel privileged to receive and share these stories. They are gifts that help all of us to make sense and meaning out of a pivotal moment in time. I know there are many more stories to be told and I hope this edition of Critical Dietetics inspires you to tell yours. To know we are not alone in our struggles is to find strength and opportunity in the support we offer one another as members of the Critical Dietetics community. I would love to hear about your experiences. Feel free to email me at afox@stfx.ca.

\section{Author Bio:}

Ann is a dietitian and the Chair of the Department of Human Nutrition at St. Francis Xavier University in Antigonish, Nova Scotia, Canada. Her research explores health professional practice, the arts and health interface, and community health. Ann is committed to learning about and supporting Indigenous ways of knowing.

\section{References}

Beswick, A. (2020, March 23). Canada's Cross-border Truckers can't get Coronovirus Coverage. https://www.capebretonpost.com/ news/provincial/Canadas-cross-border-truckers-cant-get-coronavirus-coverage-426294/

Brady, J. (2017). Trading the Apron for a White Lab Coat: a Contemporary History of Dietetics in Canada, 1954 to 2016. Doctoral Thesis. Kingston, Ontario, Canada: Queen's University.

Burki, T. (2020). The Indirect Impact of COVID-19 on Women. The Lancet, 904-905. www.thelancet.com/infection

Butler, M. J., \& Barrientos, R. M. (2020). The Impact of Nutrition on Covid-19 Susceptibility and Long-Term Consequences. Brain, Behaviour and Immunity, 53-54.

Calder, P. C. (2020). Nutrition, Immunity and COVID-19. BMJ Nutrition, Prevention \& Health, I-19.

Charlebois, S. (2020, August 19). Things will Never be the Same at Canadian Grocery Stores. Here is Why. Retail Insider, pp. I-4.

Coelho- Ravagnani, C. d., Campos Corgosinho, F., La Flor Ziegler Sanches, F., Marques Maia Prado, C., Laviano, A., \& Felipe Mota, J. (2020). Dietary Recommendations during the COVID-19 Pandemic. Nutrition Reviews, I-I4.

Derbyshire, E., \& Delange, J. (2020). COVID-19: Is there a Role for Immunonutrition, Particularly in the over 65s? BMJ Nutrition, Prevention \& Health, I-6.

Galanakis, C. M. (2020). The Food Systems in the Rra of the Coronavirus (COVID-19) Pandemic Crisis. Food, I-IO.

Hastie, B. (2020, May 12). The Coronavirus reveals the Necessity of Canada's Migrant Workers. The Conversation, pp. I-5.

Jalava, K. (2020). First Respiratory Transmitted Food Borne Outbreak? Internaitonal Journal of Hygiene and Environmental Health, I-3.

Liu, Q., Zheng, Z., Zheng, J., Chen, Q., Liu, G., Chen, S., Chu, B., Zhu, H., Akinwunmi, B., Huang, J., Zhang, C., \& Ming, W. K. (2020). Health Communication Through News Media During the Early Stage of the COVID-19 Outbreak in China: Digital Topic Modeling Approach. Journal of medical Internet research, 22(4), el91/8. https://doi.org//0.2196/191/8

Lupton, A. (2020, March 17). COVID-19 Restrictions on Migrant Workers will be Devastating Ontario Farmers Warn. https://www.cbc. ca/news/canada/london/covid-19-restrictions-on-migrant-workers-will-be-devastating-ontario-farmers-warn-1.5500269

Shalvey, K. (2020, December 24). More than 400 Amazon Workers have been Infected wiht COVID-19 at Canadian Facilities, where Working Conditions are described as 'Hell'. https://www.businessinsider.com/more-than-400-covid-cases-reported-amazoncanada-facilities-2020-12

Tam, T. (2020). From Risk to resilience: an Equity Approach to COVID-19, The Chief Public Health Officer of Canada's Report on the State of Public Health In Canada in 2020. Ottawa: Public Health Agency of Canada.

Taylor, C. A., Boulos, C., \& Almond, D. (2020). Livestock Plants and COVID-19 Transmission. PNAS, 31705-317I5.

Taylor, D., Pritchard, A., Duand, D., \& Mishra, S. (2020, August 10). What's Behind the Empty Grocery Shelves. Supply Chain Management Review, pp. I-4.

Turnbull, S. (2020, June 19). 'Hero' Grocery Store Workers should get 'Properly' Paid, PM says. https://www.ctvnews.ca/politics/herogrocery-store-workers-should-get-properly-paid-pm-says-1.4991682

Walsh, F. (2020). Loss and Resilience in the Time of COVID-19: Meaning Making, Hope and Transcendence. Family Process, 898-911.

Winskill, P., Whittaker, C., Walker, P., Watson, O., Laydon, D., Imai, N., \& Cuomo-Dannenburg, G. (2020). Report 22: Equity in Response to the COVID-19 Pandemic: an Assessment of the Direct and Indirect Impacts on Disadvantaged and Vulnerbale Populations in Low- and Lower Middle-Income Countries. London: Imperial College.

Yearby, R. (2021, February 26). Meatpacking Plants have been Deadly COVID-19 Hot Spots- but Policies that Encourage Workers to Show up Sick are Legal. The Conversation, pp. I-5. 